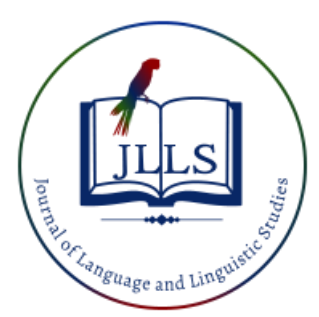

ISSN: 1305-578X

Journal of Language and Linguistic Studies, 17(2), 1114-1119; 2021

\title{
Perceived language barriers among foreign nationals in Turkey
}

\author{
K.M Ashifa ${ }^{\text {a }}$ iD \\ APA Citation: \\ ${ }^{a}$ Istanbul Gelisim University, Turkey \\ Ashifa, K.M. (2021). Perceived language barriers among foreign nationals in Turkey. Journal of Language and Linguistic Studies, 17(2), \\ 1114-1119. Doi: $10.52462 / \mathrm{jlls} .78$ \\ Submission Date:21/02/2021 \\ Acceptance Date:20/05/2021
}

\begin{abstract}
Turkey has been attracting an increasing number of foreigners seeking to work or create a social life in the country over the last few years. Naturally, like with any country, there are some problems that foreigners may encounter in Turkish life due to cultural differences. While these difficulties are not unique to Turkey and there may be obstacles to overcome, Turkish life continues to adhere to international norms. One of the most significant obstacles foreigners face in Turkish day today life is the issue of communication. The language barrier is the most significant obstacle since it impairs one's capacity to communicate with others, which is necessary for survival. It might generate difficulties for newcomers, such as finding work, acquiring an education, obtaining medical treatment, acquiring housing, and generally surviving. With an increase in foreign mobility to Turkey, adaptation challenges and issues become more prevalent. Adaptation to a new culture occurs on a variety of levels, including social, psychological, academic, and environmental. Adapting properly to a new culture is critical for social and academic success. Adapting to a new culture and way of life, on the other hand, has never been easy. The present investigation came to be signify the various challenges faced by the foreign nationals with language barrier.
\end{abstract}

Keywords: Language barriers; Foreign Nationals; Communication; Life style; satisfaction.

\section{Introduction}

The twenty-first century has brought about an entirely new form of environmental engagement, making previous methods obsolete. There has been a huge growth in the desire for economic, technological, political, social, and cultural connections as a result (KALDIRIM \& DEGEÇ, 2017). Nowadays, the capacity to converse with people who speak a foreign language is seen as a useful tool for broadening one's world viewpoint through exposure to diverse cultures (Rost, 2014). (Rost, 2014), and recognition of their cultural choices and prejudices (Root \& Ngamprnchai, 2013). Turkey is situated at the crossroads of Asia, Europe, and Africa, and as a result of its geographical location, the increase in the number of foreign students studying at Turkish universities, and the improved foreign relations of Turkish businesses in terms of economic activity, international institutions, foundations, and media, Turkey is home to a diverse range of cultures and civilizations. This degree of effort and cooperation has regularly propelled Turkey to the forefront of discussions, which has increased interest in Turkish as a foreign language acquisition (KALDIRIM \& DEGEÇ, 2017).

\footnotetext{
${ }^{1}$ Corresponding author.

E-mail address: ashifakattur@gmail.com
} 
The language barrier is the most significant obstacle since it impairs one's capacity to communicate with others, which is necessary for survival. It might generate difficulties for newcomers, such as finding work, acquiring an education, obtaining medical treatment, acquiring housing, and generally surviving. Turkey has been attracting an increasing number of foreigners seeking to work or create a social life in the country over the last few years. Naturally, like with any country, there are some problems that foreigners may encounter in Turkish life due to cultural differences. While these difficulties are not unique to Turkey and there may be obstacles to overcome, Turkish life continues to adhere to international norms. One of the most significant obstacles foreigners face in Turkish business life is the issue of communication. While it is widely accepted that knowledge of English is critical for Turkish citizens in both school and industry, many people struggle with the language and are unable to communicate successfully. While many people speak English proficiently at worldwide companies, operating in a country where no one knows or speaks English will provide a significant obstacle. Thus, communication difficulties vary according to where you work, but if you wish to work in Turkey and intend to stay for an extended period of time, it is suggested that you learn Turkish. Apart from employment, in daily life, on the street, in a restaurant, or at a cafe, will encounter Turkish people, and learning Turkish will benefit greatly. The present investigation came to be signify the various challenges faced by the foreign nationals with language barrier.

\section{Review of Literature}

"The emerging studies in this area focus mostly on the disruptive effects of language diversity, and tackle it as a barrier to effectiveness and to doing international business due to communication problems" ( Jonsen, Maznevski, \& Schneider, 2011). "Difficulties encountered in spoken language may not be the only obstacle in terms of language barriers. Understanding written materials, completing paperwork, and problems experienced with the use of interpreters are also important obstacles patients may face" (Cheng IH, Drillich A, \& Schattner P,2015). March \& Simon (1958) noted " the inadequacy of language for communicating about intangible and non-standardized objects and expressed the belief that 'language compatibility' shapes the usage of communication channels in organizations". Consistent with this view, Bechky (2003) found "misunderstandings due to occupational language differences in a study of a semiconductor equipment manufacturing company", and "trust formation is a team process that particularly merits a language-sensitive investigation, as it is both crucial for the functioning of MNTs and very likely to be influenced by language effects" (Tenzer, H., Pudelko, M. \& Harzing, A, 2014). "Growing evidence documents the fact that language barriers indirectly impact the quality of the healthcare that patients receive. Language barriers contribute to reducing both patient and medical provider satisfaction, as well as communication between medical providers and patients" (Shamsi, Almutairi, Mashrafi, \& Kalbani, 2020). A study conducted by Wong Fillmore (2004), which states that "Academic success of international students depends on how skill fully they use academic language in their studies. The mastery of academic language is regarded as one of the most important factors that distinguish successful students from unsuccessful ones". Demir \& Genç (2019) "revealed that insufficient vocabulary range is the primary source of difficulties international students encounter during the instruction of their content courses. Moreover, instructors are of the opinion that students have much more difficulties in using academic Turkish than they themselves perceive. It is hoped that the results of the present study will contribute to the development of curriculum and materials in such a way as to use it for the benefit of international students pursuing their studies at Turkish universities". Many researchers tried to understand the adaptation challenges of international students. For example Titrek et al., (2016) found that "international students face problems related to communication, accommodation, health and cultural issues in their stay in Turkey". From the extent of above literature it can be state that, 
inefficacy of local language may affect social, cultural, political, educational and health lives of foreign national in vast extent.

\section{Methodology}

Present investigation is perceived to understand challenges faced by the foreign national due to language barrier. The conducted among ninety six foreigners with various status as students, working professionals, tourists and entrepreneurs by using a question pool. The survey was divided into different sections, questions pertaining to their nationality, mother tongue, occupational status, education level and level of Turkish proficiency. The study also tried to assess the specific problems caused by language barriers, challenges faced, and used strategies to overcome relating to their language barrier. Collected data have analysed with SPSS Version 24 with percentage analysis and other statistical techniques which is relevant to the study.

\section{Result and Discussion}

The study tried to analyse the challenges faced by the foreign nationals in Turkey due to lack of local language proficiency. Social profile of the respondents have analysed which includes purpose of residence in turkey and clarification on their mother tongue. The study further analysed problems caused by language barriers, challenges faced, and used strategies to overcome relating to their language barrier. The social profile of respondents were shown in the following table 1 .

Table 1. Social Profile of the Respondents

\begin{tabular}{|l|l|l|}
\hline Particulars & Items & Percentage \\
\hline \multirow{4}{*}{ Gender } & Male & 54.3 \\
\cline { 2 - 3 } & Female & 45.7 \\
\hline \multirow{4}{*}{ Occupation } & Married & 37.4 \\
\cline { 2 - 3 } & Unmarried & 53.1 \\
\cline { 2 - 3 } & Other & 9.5 \\
\hline \multirow{4}{*}{ Purpose of Residence } & Student & 43.1 \\
\cline { 2 - 3 } & Academician & 18.3 \\
\cline { 2 - 3 } & Entrepreneurs & 23.5 \\
\cline { 2 - 3 } & Other & 15.1 \\
\hline & Student & 43.1 \\
\cline { 2 - 3 } & Working Professional & 39.3 \\
\hline \multirow{5}{*}{ Mother Tongue } & English & 17.6 \\
\cline { 2 - 3 } & Arabi & 19.1 \\
\cline { 2 - 3 } & Other & 42.8 \\
\hline
\end{tabular}

Social profile of the foreign national in the study showed that 54.3 percent of them under male and among them 45.7 percent were females. Majority of the respondent were (53.1 percent) were unmarried and 37.4 percent of the respondent was married. The study further revealed that among them 43.1 were student, 18.3 percent of them were academicians, 23.5 percent of them were entrepreneurs and 15.1 percent were being part of other sector jobs like tourism and hospitality. The 
classified respondents on the basis of their mother tongue, which revealed that 42.8 percent of them from Arab nations , 19.1 percent accepted that English is their mother tongue, and 38.1 percent of the respondents were from other Asian and African countries.

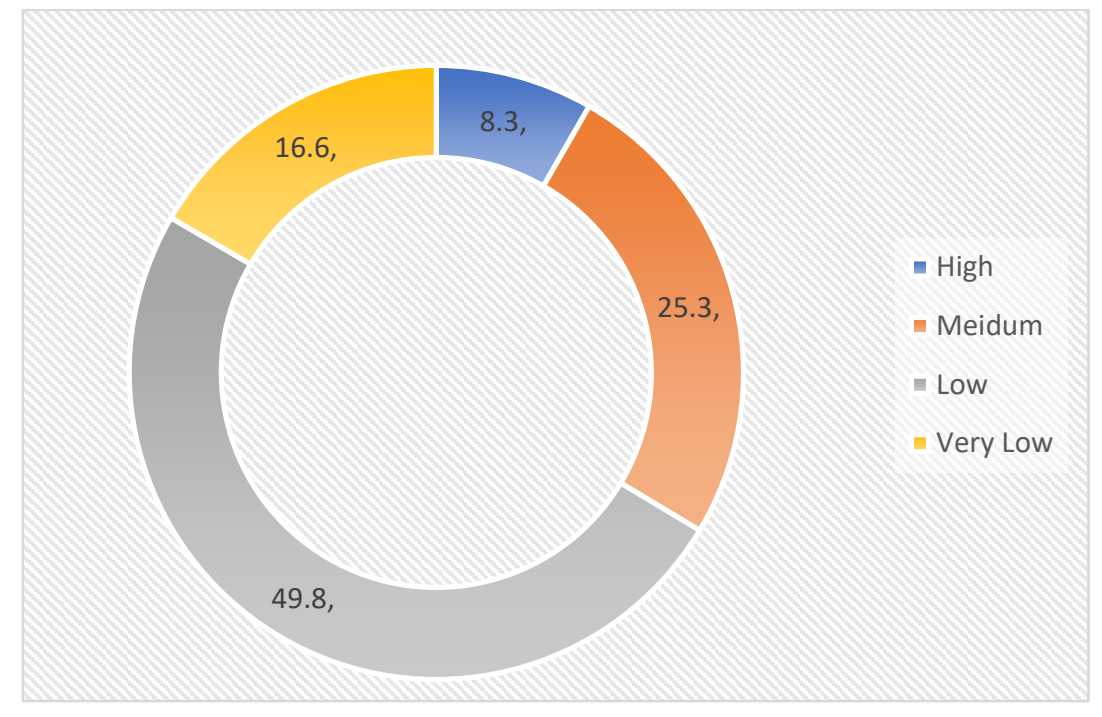

Figure 1. Turkish language proficiency among the respondents

Figure 1 represents Turkish language proficiency of the respondents. The study revealed that 49.8 percent of the respondent have had very low level of language proficiency and 25.3 of them had medium level. The result can be inferred that, the foreign nationals in Turkey is facing language barrier due to lack of local language proficiency.

Most respondents revealed the difficulties due to lack of language proficiency in their day today lives while making phone calls, purchasing food stuffs from street, dealing with local market and even they face difficulty while get around the city. They have difficulty communicating with experts such as lawyers, doctors, and government agents because they respect these individuals and do not want to make a mistake when conversing with them. Several respondents stated that they struggle with pronunciation, comprehending what others are saying, and organizing their thoughts. Very few of the respondents indicated that they require assistance from an interpreter, especially to communicate with health care professionals. Shame was the most frequently expressed emotion due to language barrier with natives. Other adjectives used to describe their feelings included frustrated, feeling like a child learning to speak, stressed, stupid, lost, challenged, terrible, lonely, afraid, restricted to using their hands to communicate, negative body language from the person speaking to (which makes them want to shut down), sad, nervous, angry, useless, powerless, depressed, and bad. Additionally, they are restricted and uneasy in the presence of native speakers. And felt inconvenient in their way of life. They have a sense of helplessness, depression, stupidity, and anxiety. Among the several difficulties individuals confront, the inability to interact freely was the most frequently cited difficulty, followed by a lack of privacy and freedom to communicate effectively with others. They claimed that life would be more joyful if they could use language fluently. They can attend college and university fruitfully, watch movies without subtitles, and easily read the newspaper. Others expressed a desire for a private instructor, daily interactive sessions, and access to the world's greatest publications. Several individuals expressed a desire for an interpreter. 


\section{Conclusion}

The critical question is whether the language barrier is a social issue (inadequate support for newcomers), an individual issue (how much effort do learners put into their language studies), or is it not a problem nor an issue at all; it is simply the way life is. In an ideal world, all arrivals would have their own personal professional interpreters, rather than untrained family members. However, overcoming linguistic obstacles requires a two-way street. Language learners might abandon their too lofty objective of fluency and instead concentrate on what is more urgent. The language barrier and its effects on Adult Newcomers speech in order to become functional in the language. Language learning is a never-ending process, and they have the remainder of their lives to achieve fluency. Native speakers, by the way they speak, might contribute to language difficulties. Thus, if native speakers communicate slowly and clearly, checking to ensure that the person with whom they are conversing understands what they have said, avoiding idioms, and most importantly, being patient, they can significantly reduce obstacles.

\section{References}

Akbaş, E. (2012). Exploring metadiscourse in master's dissertation abstracts: cultural and linguistic variations across postgraduate writers. International Journal of Applied Linguistics and English Literature, 1(1), 12-26.

Bechky, B.. (2003): "Sharing Meaning Across Occupational Communities: The Transformation of Understanding on the Production Floor," Organization Science, 14, 312-330.

Cheng IH, Drillich A, Schattner P. (2015). Refugee experiences of general practice in countries of resettlement: a literature review. The British journal of general practice : the journal of the Royal College of General Practitioners, 65(632), e171-6.

Demir , D., \& Genç, A. (2019). Academic Turkish for international students: Problems and suggestions*. Journal of Language and Linguistic Studies, 15(1), 34-47

Jonsen, K., Maznevski, M. L., \& Schneider, S. C. 2011. Diversity and its not so diverse literature: An international perspective. International Journal of Cross Cultural Management, 11(1): 35-62.

KALDIRIM, A., \& DEGEÇ, H. (2017). Difficulties that Students who Learn Turkish as a Foreign Language Encounter During Listening Skills. Journal of Educational Science Research, 7(1), https://dergipark.org.tr/tr/download/article-file/698113.

Kassis Henderson, J. 2005. Language diversity in international management teams. International Studies of Management and Organization, 35(1): 66-82.

Koç, M. H., \& Fidan, T. (2020). Teachers' opinions on ethical and unethical leadership: A phenomenological research. Educational Administration: Theory and Practice, 26(2), 355-400. doi:10.14527/kuey.2020.008

Lagerström, K., \& Andersson, M. 2003. Creating and sharing knowledge within a transnational team: The development of a global business system. Journal of World Business, 38(2): 84-95.

March, J. G . \& H. A. Simon (1958): Organizations. New York: Wiley. Rand Journal Of Economics, 17, 18-32.

Root, E., \& Ngamprnchai, A. (2013). I came back as new human being: student descriptions of intercultural competence acquired through education abroad experiences. Journal of Studies in International Education, 5(17), 513-532. 
Rost, M. (2014). Listening in a multilingual world: the challenges of second language (L2) listening. The International Journal of Listening, 28(3), 131-148.

Shamsi, H. A., Almutairi, A. G., Mashrafi, S. A., \& Kalbani, T. A. (2020). Implications of Language Barriers for Healthcare: A Systematic Review. Oman Medical Journal, 35(2).

Tenzer, H., Pudelko, M. \& Harzing, AW. The impact of language barriers on trust formation in multinational teams. J Int Bus Stud, 45, 508-535 (2014). https://doi.org/10.1057/jibs.2013.64

Tietze, S. 2007. Language and international management: Emergent themes and new perspectives. Bradford University School of Management, Working Paper No 07/35. Available online: http://www.brad.ac.uk/acad/management/external/pdf/w orkingpapers/2007/Booklet_0735.pdf, accessed 24 September 2013.

Titrek, O., Hashimi, S. H., Ali, S., \& Nguluma, H. F. (2016). Challenges Faced by International $\begin{array}{llll}\text { Students in Turkey. The Anthropologist, } & \text { 148- }\end{array}$ 156. https://doi.org/10.1080/09720073.2016.11892000

Türkkan, B., \& Yağcıoğlu, S. (2006). Türkçe bilimsel metinlerde gönderimsel bağdaşıklık ve köprü gönderimi: Merkezleme kuramı çerçevesinde bir yaklaşım. Dilbilim Araştırmaları Dergisi, 59-70.

Y1lmaz, İ. (2017). Opinions of Turkish as a foreign language learners on academic Turkish. Advances in Language and Literary Studies, 8(2), 180-189

\section{AUTHOR BIODATA}

Dr. K.M. Ashifa is a doctorate holder in social work and currently working as Assistant Professor in Department of Social Work, Faculty of Health Science, Istanbul Gelisim University, Istanbul, Turkey. She served as a State coordinator for Human Rights Education under UN World Programme in Kerala for the year 2008-2011. She also worked as Asst. Professor and Head of the Department of Social Work at Kalasalingam Academy of Research and Education from 2015-2019, in India. Her enthusiasm in research proved by receiving Innovative Academic Research and Dedicated teaching faculty award from Society of Engineers \& Technicians, Malaysia, International Research Award from Archers \& Elevators, Bangalore India and also she recipient of Best paper ward from International Conference on Conference on Multi - Disciplinary Research Studies and Education ( ICMDRSE 19). 